\title{
PREDIKSI KARAKTERISTIK TERMOFLUIDA PROSES PERPINDAHAN PANAS DI DALAM RUANG BAKAR INCINERATOR
}

\author{
Veronica Indriati Sri Wardhani \\ Pusat Sains dan Teknologi Nuklir Terapan - BATAN \\ Jl. Tamansari 71 Bandung, 40132 \\ Email: vero@batan.go.id \\ Diterima:15-10-2014 \\ Diterima dalam bentuk revisi: 16-01-2014 \\ Disetujui: 26-01-2015
}

\begin{abstract}
ABSTRAK
PREDIKSI KARAKTERISTIK TERMOFLUIDA PROSES PERPINDAHAN PANAS DI DALAM RUANG BAKAR INCINERATOR. Penanganan limbah padat dengan proses pembakaran merupakan salah satu cara yang efektif sampai saat ini, instalasi incinerator masih menjadi perlatan pilihan yang dipergunakan untuk proses pembakaran. Namun penggunaan incinerator sebagai alat pembakaran sampah harus direncanakan dengan baik, karena efek yang dihasilkan adalah produk-produk destruktif yang justru bernilai negatif terhadap lingkungan. Mengingat proses pembakaran yang sangat kompleks di dalam incinerator, maka dilakukan simulasi dengan membuat suatu pemodelan menggunakan perangkat lunak computational fluid dinamics (Fluent). Simulasi ini bertujuan untuk melihat karakteristik termo fluida yang terjadi di dalam ruang bakar incinerator meliputi variabel-variabel antara lain distribusi temperatur, sifat-sifat fisik fluida dan jenis aliran ( laminer atau turbulen ). Variabel-variabel tersebut akan mempengaruhi harga koefisien perpindahan panas konveksi (h). Perhitungan karakteristik termofluida yang meliputi panas yang mengalir (Q) dan koefisien perpindahan panas (h) pada tiga (3) titik pengukuran arah aksial diperoleh hasil koefisien perpindahan panas konveksi di ruang bagian dalam lebih besar 10 kali dari koefisien perpindahan panas konveksi di ruang bagian luar antara bata dalam dan bata luar.
\end{abstract}

Kata kunci: Incinerator, perpindahan panas, karakteristik termofluida, koefisien perpindahan panas konveksi.

\begin{abstract}
THERMOFLUID CHARACTERISTIC PREDICTION OF HEAT TRANSFER IN THE COMBUSTION CHAMBER OF INCINERATOR. Handling of solid waste with the combustion process by installing the incinerator, is one effective way at present. However, the use of incinerators as a means of burning waste should be well planned, because of the resulted destructive products that have a negative impact to the environment. Considering the complexity process of combustion in the incinerator, the process simulation is done by using Computational fluid Dynamics software (Fluent). This simulation is proposed to obtain thermofluid characteristics such as variable temperature distribution, physical properties of the fluid and flow pattern (laminer or turbulent). These variables will affect the convection heat transfer coefficient $(h)$. The Calculation characteristics of termofluida such as heat flow (Q) and coefficient heat transfer (h) on three (3) points in axial direction obtained the coefficient heat transfer convection inner space is greater 10 times than the coefficient heat transfer convection outer space between the inner brick and the outer brick
\end{abstract}

Keywords: Incinerator, heat transfer, thermofluid characteristics, heat transfer coefficient. 
Jurnal Sains dan Teknologi Nuklir Indonesia

Indonesian Journal of Nuclear Science and Technology

Vol. 16, No 1, Februari 2015; 41-50

\section{PENDAHULUAN}

Berbagai kegiatan yang dilakukan di lembaga penelitian di bidang nuklir akan menghasilkan sampah radioaktif. Pengolahan sampah radioaktif yang berbentuk padat salah satunya dapat dilakukan melalui proses pembakaran dengan menggunakan suatu alat incinerator. Di dalam incinerator, sampah dibakar secara terkendali hingga dihasilkan abu (15\%) dan gas yang memerlukan penanganan lebih lanjut. Di samping itu alat ini dapat mengandung gas pencemar berupa: NOx, SOx dan lain-lain yang dapat mengganggu kesehatan manusia, menimbulkan air kotor saat proses pendinginan gas maupun proses pembersihan incinerator dari abu maupun terak. Insinerasi merupakan proses pengolahan limbah padat dengan cara pembakaran untuk mereduksi sampah mudah terbakar (combustible) yang sudah tidak dapat didaur ulang lagi, membunuh bakteri, virus, dan kimia toksik. Insinerasi pada dasarnya ialah proses oksidasi bahan-bahan organik menjadi bahan anorganik. Prosesnya sendiri merupakan reaksi oksidasi cepat antara bahan organik dengan oksigen $(1,2)$. Proses in-sinerasi berlangsung melalui 3 tahap, yaitu: 1) mengubah air dalam sampah menjadi uap air, hasilnya limbah menjadi kering yang akan siap terbakar, 2) proses pirolisis yaitu pembakaran tidak sempurna dimana temperatur belum terlalu tinggi, 3) proses pembakaran sempurna. Insinerasi dapat mengurangi berat sampah hingga $70 \%$ - $80 \%$ (3).

Pembakaran sampah merupakan suatu reaksi oksidasi yang membutuhkan sejumlah udara. Udara merupakan oxidizer alami dimana pada keadaan normal memiliki kandungan oksigen sebesar $21 \%$. Setelah bahan bakar berubah fase menjadi gas dan bersifat mudah terbakar, bahan bakar akan dengan mudah bercampur dengan udara sebagai oksidator, kemudian ketika reaksi campuran udara dan bahan bakar sudah cukup panas, nyala api akan terbentuk sebagai tanda terjadinya proses pembakaran (4). Temperatur pembakaran yang optimum dan seragam sangat dibutuhkan pada proses ini (5). Efektivitas pembakaran sangat bergantung pada banyaknya oksigen yang bereaksi di dalam ruang bakar. Banyaknya oksigen sangat ditentukan oleh pola aliran udara yang mengalir dan proses perpindahan panas di dalam ruang bakar incinerator, proses ini biasa disebut proses termofluida. Proses termofluida ini sangat tergantung dari aliran dan perbedaan temperaturnya, yang dinyatakan dalam karakteristik termofluida. Dari karakteristik termofluida tersebut dapat diketahui unjuk kerja ruang bakar incinerator. Oleh karena itu penelitian ini dilakukan dengan tujuan untuk melihat karakteristik termofluida yang terjadi di dalam ruang bakar incinerator.

Karakteristik termofluida yang terjadi di dalam ruang bakar incinerator meliputi variabel-variabel antara lain : distribusi temperatur, sifat-sifat fisik fluida dan jenis aliran (aliran laminer atau turbulen). Variabel variabel tersebut akan mempengaruhi harga koefisien perpindahan panas konveksi yang akan menentukan besarnya distribusi panas. Konsep yang digunakan untuk mencari koefisien perpindahan panas konveksi adalah didasarkan kepada dua mekanisme perpindahan panas yaitu perpindahan panas secara konduksi dan perpindahan panas se- 
cara konveksi (6). Dalam penelitian ini dilakukan prediksi karakteristik termofluida proses perpindahan panas di dalam ruang bakar incinerator dengan cara simulasi menggunakan perangkat lunak computational fluid dynamics (CFD) $(7,8)$. Perangkat lunak ini dapat digunakan untuk simulasi aliran fluida dan perpindahan panas secara bersamaan.

Simulasi dinamika aliran fluida dilakukan dengan membuat suatu pemodelan incinerator untuk memprediksi distribusi panas, distribusi temperatur dan pola aliran fluida di dalam incinerator. Data distribusi temperatur dan pola aliran yang diperoleh di pergunakan untuk menghitung harga koefisien perpindahan panas konveksi (h). Dari perhitungan ini diharapkan diperoleh hasil yang signifikan untuk memprediksi proses pembakaran dan perpindahan panas yang terjadi di dalam incinerator efektif.

\section{TEORI}

Energi dalam bentuk panas dapat berpindah melalui medium maupun tanpa medium. Oleh karena itu medium yang dilalui sangat menentukan laju perpindahan panasnya. Berdasarkan medium yang dilaluinya, maka ada tiga (3) mekanisme perpindahan panas yaitu perpindahan kalor konduksi, konveksi dan radiasi.

Perpindahan panas secara konduksi adalah perpindahan panas yang terjadi pada medium padat. Perpindahan panas konduksi terjadi karena adanya perambatan panas dari benda satu yang temperaturnya lebih tinggi ke benda lainnya yang lebih rendah temperaturnya, karena ke dua benda bersinggungan. Perpindahan panas konduksi ini tidak diikuti perpindahan massa. Rumus laju perpindahan panasnya adalah $(9,10)$ :

$$
q=k A \frac{\Delta T}{\Delta x}
$$

Di mana:

$\mathrm{q}=$ jumlah energi yang dipindahkan (W)

A $=$ luas penampang $\left(\mathrm{m}^{2}\right)$

$\Delta \mathrm{T}=$ beda temperatur dalam arah perpindahan panas $\left({ }^{\circ} \mathrm{C}\right)$

$\Delta \mathrm{x}=$ jarak dalam arah perpindahan panas (m)

$\mathrm{k}=$ konduktivitas termal bahan $\left(\mathrm{W} / \mathrm{m}^{\circ} \mathrm{C}\right)$

Perpindahan panas secara konveksi adalah perpindahan panas yang terjadi pada medium gas dan cair dan disertai dengan perpindahan massa. Adapun rumus laju perpindahan panasnya adalah (11):

$$
q=A h_{c} \Delta T
$$

Di mana:

$\Delta \mathrm{T}=$ beda temperatur antara permukaan padat dengan fluida di sekelilingnya $\left({ }^{\circ} \mathrm{C}\right)$

$\Delta \mathrm{T}=\mathrm{Tm}-\mathrm{Tw}$

$\mathrm{Tm}=$ Temperatur rata - rata fluida $\left({ }^{\circ} \mathrm{C}\right)$

$\mathrm{Tw}=$ Temperatur rata - rata dinding $\left({ }^{0} \mathrm{C}\right)$

$\mathrm{h}_{\mathrm{c}}=$ koefisien perpindahan panas konveksi $\left(\mathrm{J} / \mathrm{m}^{2 \circ} \mathrm{C}\right)$

$A=$ luas permukaan pemindah panas $\left(\mathrm{m}^{2}\right)$

$\mathrm{Q}=$ jumlah panas yang merambat persatuan waktu (W)

Koefisien perpindahan panas $h$ tergantung dari dimensi dan kondisi aliran, pada perpindahan panas konveksi paksa, kondisi aliran laminer dan turbulen ditentukan oleh besarnya bilangan Reynold yang dituliskan dalam persamaan:

$$
R_{e D}=\frac{\rho u_{m} D}{\mu}
$$

Di mana :

$\rho=$ massa jenis $\left(\mathrm{kg} / \mathrm{m}^{3}\right)$

$u_{m}=$ kecepatan aliran $(\mathrm{m} / \mathrm{s})$

$\mathrm{D}=$ diameter dinding dalam dan luar $(\mathrm{m})$

$\mu \quad=\quad$ viskositas dinamik $(\mathrm{kg} / \mathrm{m} . \mathrm{s})$ 
Jurnal Sains dan Teknologi Nuklir Indonesia

Indonesian Journal of Nuclear Science and Technology

Vol. 16, No 1, Februari 2015; 41-50

Kondisi aliran laminar bilangan Reynoldnya

$\operatorname{Re}<2300$, aliran transisi bilangan Reynold

nya $2300<\mathrm{Re}<4000$ dan aliran turbulen

bilangan Reynold $\operatorname{Re}>4000$ (12).

Perpindahan panas radiasi adalah proses di mana panas memancar dari benda yang bersuhu tinggi ke benda yang bersuhu rendah bila dua benda itu terpisah di dalam ruang hampa. Energi panas yang melalui ruang hampa tersebut dalam bentuk gelombang elektromagnetik. Bila energi radiasi menimpa suatu bahan, maka sebagian radiasi dipantulkan, sebagian diserap dan sebagian diteruskan. Laju penyerapan kalor yang dipancarkan secara radiasi dirumuskan (13) :

$$
q=\partial A\left(T_{1}^{4}-T_{2}^{4}\right)
$$

Di mana : $\partial=$ konstanta Stefan-Boltzman $=$ $5,669 \times 10-8 \mathrm{~W} / \mathrm{m}^{2} \mathrm{~K}^{4}$

$A=$ luas permukaan benda $\left(\mathrm{m}^{2}\right)$

$\mathrm{T}=$ temperatur $\left({ }^{\circ} \mathrm{C}\right)$

$\mathrm{q} \quad=$ laju perpindahan panas $(\mathrm{W})$

\section{METODOLOGI}

Pemodelan incinerator berbentuk silinder secara simetri menggunakan perangkat lunak $C F D$, program ini membantu untuk memecahkan persamaan matematis yang merumuskan proses dinamika fluida dalam menggambarkan fenomena aliran fluida yang terjadi baik yang melibatkan panas maupun yang tidak melibatkan panas (14). Udara $\left(\mathrm{O}_{2}\right)$ masuk dari bawah dan dari samping. Dimensi dan kondisi batas incinerator yang akan dimodelkan adalah:

Tabel 1. Dimensi incinerator

\begin{tabular}{ll}
\hline \multicolumn{1}{c}{ Parameter } & \multicolumn{1}{c}{ Dimension } \\
\hline Jari-jari luar incinerator & $125 \mathrm{~cm}$ \\
Jari-jari dinding dalam bata dalam (R1) & $50 \mathrm{~cm}$ \\
Jari-jari dinding luar bata dalam (R2) & $62 \mathrm{~cm}$ \\
Jari-jari dinding dalam bata luar (R3 ) & $77 \mathrm{~cm}$ \\
Jari-jari dinding luar bata luar (R4) & $89 \mathrm{~cm}$ \\
Jari-jari bahan bakar (tumpukan sampah) & $25 \mathrm{~cm}$ and $50 \mathrm{~cm}$ \\
Tinggi incinerator & $120 \mathrm{~cm}$ \\
Tebal dinding bagian dalam dan luar & $12 \mathrm{~cm}$ \\
Diameter lubang udara samping (16 buah) & $6.25 \mathrm{~cm}$ \\
Diameter burner & $12 \mathrm{~cm}$ \\
Material dinding dalam incinerator & $\mathrm{campuran}$ semen putih, semen abu dan abu batu \\
Material dinding luar incinerator & $\mathrm{campuran}$ semen biasa dengan batu abu \\
Jumah panas total & $85 \mathrm{~kW}$ \\
Kecepatan udara pada lubang udara & $10 \mathrm{~m} / \mathrm{s}$ \\
Kecepatan udara pada burner & $10 \mathrm{~m} / \mathrm{s}$ \\
Temperatur lingkungan & $27^{\circ} \mathrm{C}$
\end{tabular}




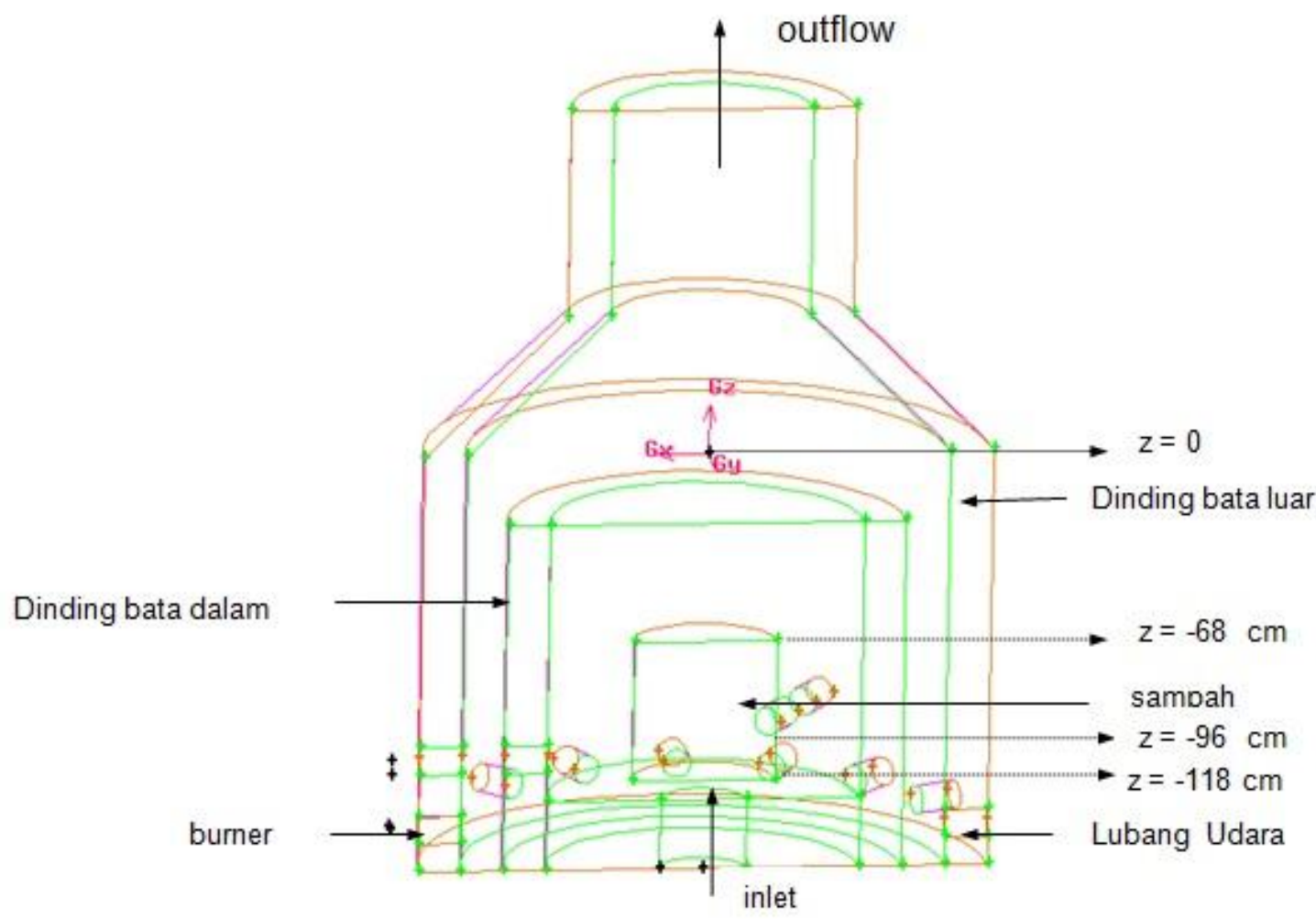

Gambar 1. Pemodelan incinerator secara simetri

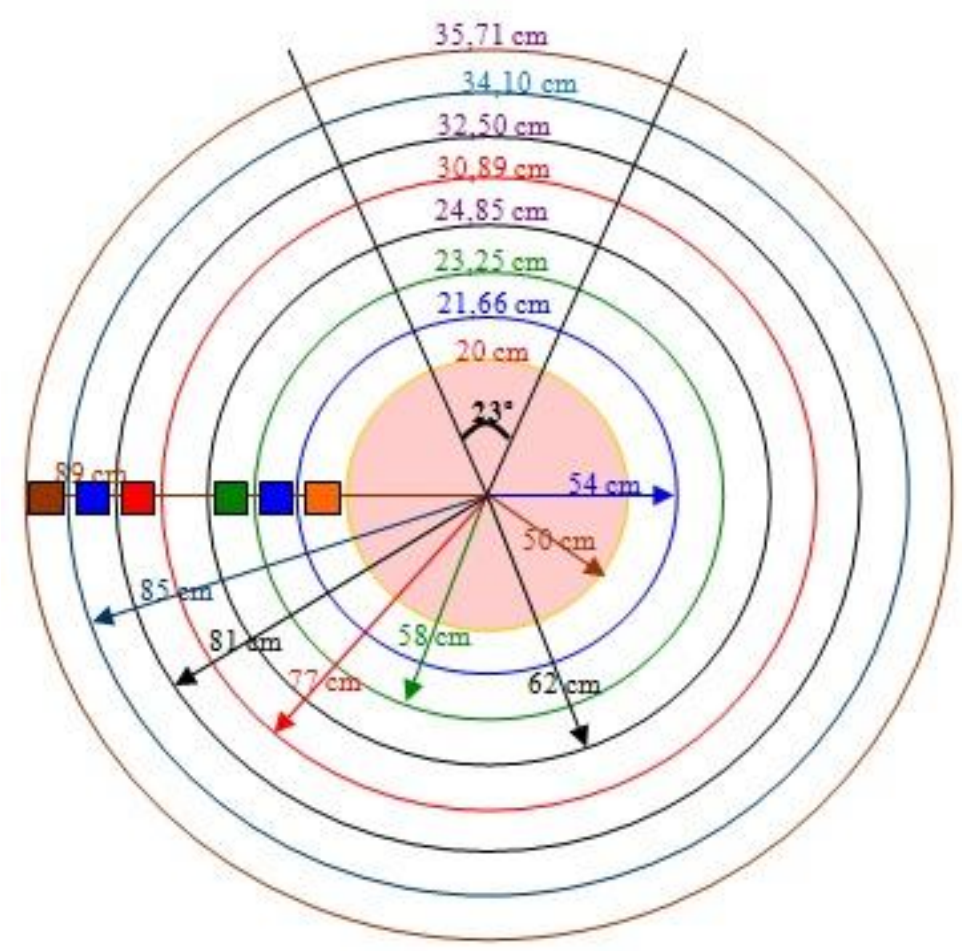

Gambar 2. Daerah yang diamati arah radial 
Proses perpindahan panas yang terjadi di dalam incinerator adalah perpindahan panas konveksi pada ruang dari tepi sampah dan dinding dalam, konduksi pada bata dinding dalam dan dinding luar, konveksi pada ruang antara dengan dinding dalam dan dinding luar. Parameter - parameter fluida yang ditunjukkan dari hasil perhitungan dengan menggunakan perangkat lunak Computational Fluid Dynamics ini adalah hasil keluaran berupa data-data distribusi temperatur dan gambar kontur. Data - data ini akan dipergunakan untuk memprediksi karakteristik thermofluida proses perpindahan panas di incinerator. Gambar hasil pemodelan dapat dilihat pada Gambar 1, sedangkan daerah yang diamati arah radial dapat dilihat pada Gambar 2.

\section{HASIL DAN PEMBAHASAN}

Pembakaran yang terjadi di dalam incinerator akan sempurna apabila dicapai temperatur yang optimum dan seragam. Oleh karena itu dibutuhkan oksigen untuk mengatur distrbusi temperatur selama pembakaran. Pada simulasi pemodelan ini akan dibahas proses perpindahan panas yang terjadi di dalam ruang bakar incinerator meliputi perpindahan panas konduksi dan konveksi, sementara pengaruh proses perpindahan panas radiasi masih diabaikan, karena emisivitasnya dianggap kecil. Proses pembakaran yang melibatkan reaksi kimia belum dimodelkan, penyederhanaan dilakukan dengan mengasumsikan bahwa panas yang timbul berasal dari permukaan sampah yang dibakar berbentuk silinder. Panas yang berpindah (Q) dan koefisien perpindahan panas (h) merupakan variabel karakteristik termofluida yang dipergunakan untuk memprediksi efektivitas perpindahan panas yang terjadi di dalam ruang bakar incinerator.

Data titik-titik pengukuran temperatur pembakaran sampah di ruang bakar diambil pada posisi $z=0 \mathrm{~cm}$ (ruang bakar bagian bawah), $z=22 \mathrm{~cm}$ (ruang bakar bagian tengah) dan $z=50 \mathrm{~cm}$ (ruang bakar bagian atas), sedangkan pada arah radial dari $x=$ 25 (bagian tepi sampah) sampai $x=100 \mathrm{~cm}$ (dinding luar incinerator). Hasil perhitungan simulasi menggunakan perangkat lunak CFD berupa gambar kontur yang dapat dilihat pada Gambar 3.

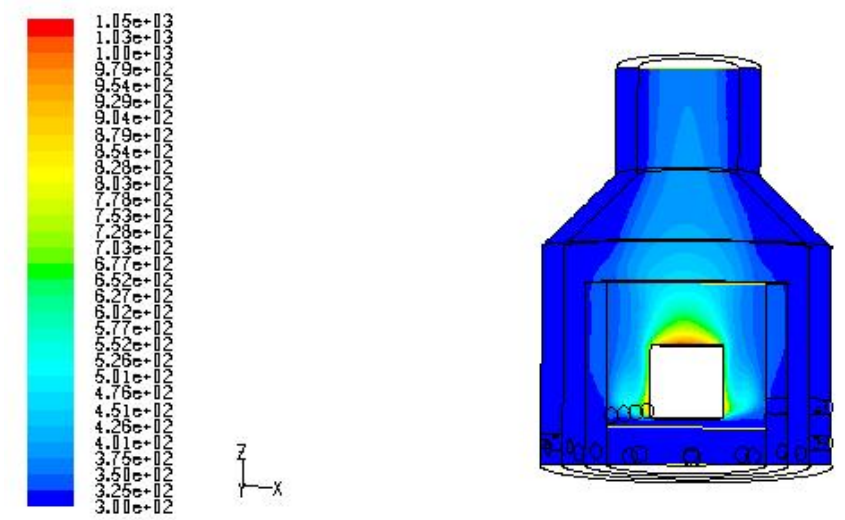

Contours of Tota] Temperature [k]

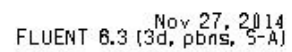

Gambar 3. Kontur distribusi temperatur dalam ruang bakar incinerator 
Sedangkan data yang disajikan dalam bentuk kurva. Distribusi tem-peratur sebagai fungsi dari jarak dari pusat incinerator ke arah radial pada posisi $z=0 \mathrm{~cm}, z=22 \mathrm{~cm}$ dan $z=50 \mathrm{~cm}$ digambarkan dalam bentuk kurva Gambar 4.

Dari Gambar 4 terlihat bahwa pada sampah di mana proses pembakaran berlangsung diperoleh harga temperatur sekitar $500{ }^{\circ} \mathrm{C}$ sampai $600{ }^{\circ} \mathrm{C}$, semakin jauh dari pusat incinerator pada arah radial temperatur menurun hingga dinding luar incinerator mencapai suhu lingkungan sekitar $28{ }^{\circ} \mathrm{C}$. Hal ini menunjukkan bahwa tumpukan sampah terbakar maksimum dan temperatur optimum yang dicapai berkisar antara $500{ }^{\circ} \mathrm{C}$ sampai $600{ }^{\circ} \mathrm{C}$. Perpindahan panas yang terjadi di dalam ruang bakar incinerator adalah perpindahan panas konveksi pada ruang dari tepi sampah dan dinding dalam, konduksi pada bata dinding dalam dan dinding luar, konveksi pada ruang antara dengan dinding dalam dan dinding luar. Untuk mengetahui perpindahan panas yang terjadi dilakukan perhitungan panas yang mengalir dari tepi sampah ke dinding luar dan dilanjutkan dengan perhitungan koefisien perpindahan panas (h), hasil perhitungan panas (Q) yang mengalir dan koefisien perpindahan panas (h) disajikan dalam bentuk kurva pada Gambar 5 dan Gambar 6.

Perubahan temperatur di dalam dinding bata dalam dan dinding bata luar sangat mempengaruhi banyaknya panas yang dipindahkan. Hal ini menunjukkan bahwa bata dinding incinerator dapat menahan panas sehingga besarnya panas yang keluar mengecil. Material yang dipergunakan pada dinding dalam incinerator berasal dari campuran semen putih, semen abu dan abu batu, sedangkan material dinding bagian luar incinerator berasal dari campuran semen biasa dengan batu abu.

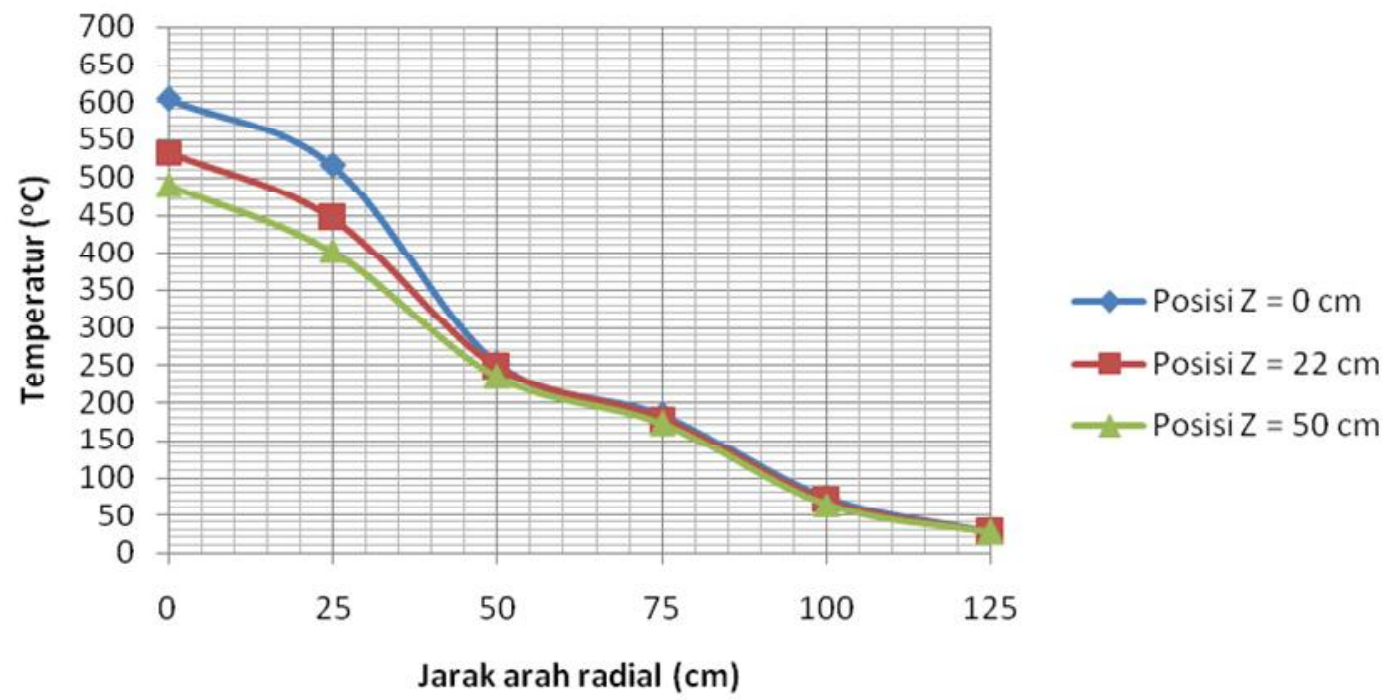

Gambar 4. Distribusi temperatur sebagai fungsi dari jarak arah radial 


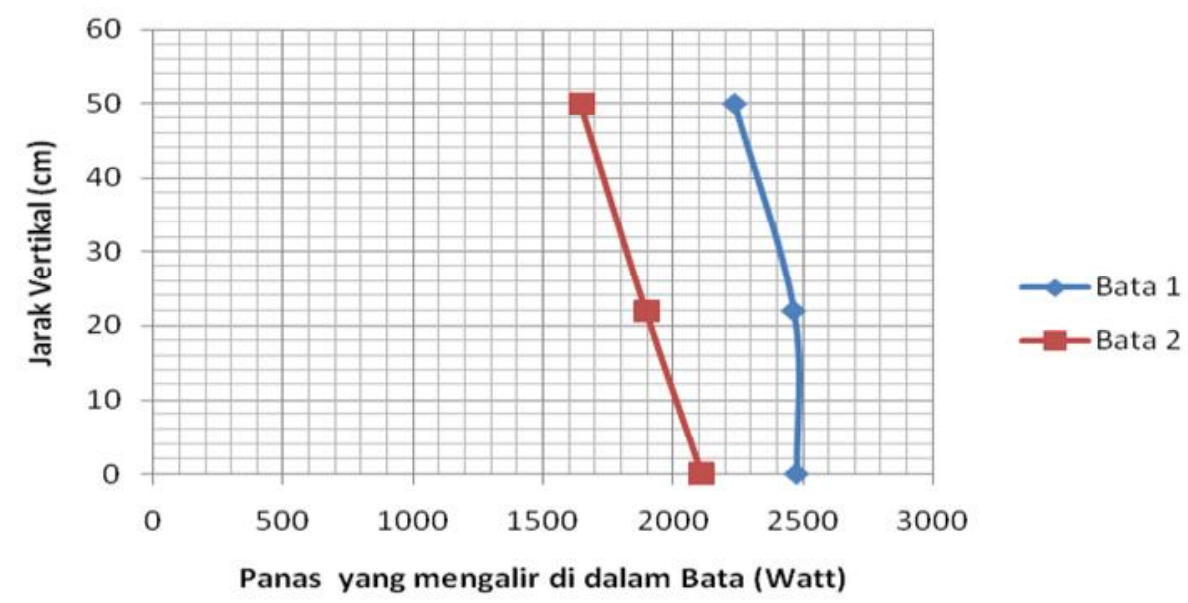

Gambar 5. Panas yang mengalir sebagai fungsi dari jarak arah vertikal

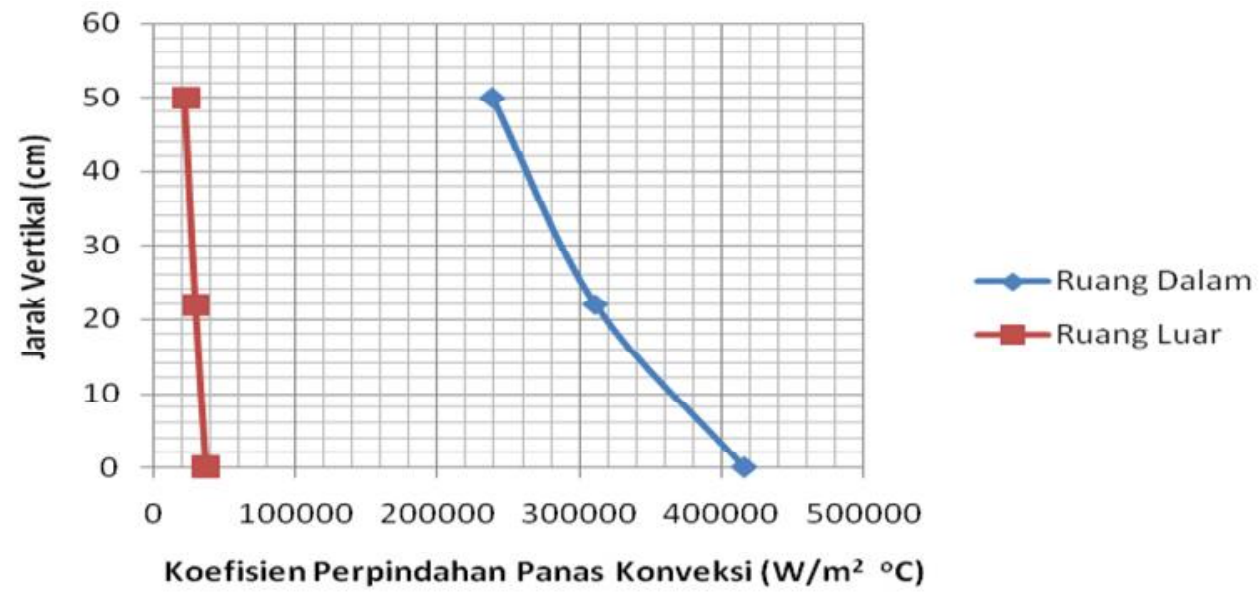

Gambar 6. Koefisien perpindahan panas sebagai fungsi dari jarak arah vertikal

Dari hasil perhitungan Gambar 5, terlihat bahwa panas yang mengalir di ruang antara tepi sampah ke dinding bata dalam makin ke atas makin rendah, demikian pula pada ruang antara bata dinding dalam ke bata dinding luar. Hal ini disebabkan karena sampah banyak terbakar di bagian bawah, semakin ke atas sampah yang terbakar semakin berkurang. Perpindahan panas konveksi terjadi pada fluida (udara) pada proses pembakaran di dalam incinerator, jenis aliran fluidanya adalah aliran turbulen dengan bilangan Reynold $(\operatorname{Re})=2.26 \times 10^{5}$. Dari kurva Gambar 6 terlihat bahwa koefisien perpindahan panas konveksi di ruang bagian dalam lebih besar daripada koefisien perpindahan panas konveksi di ruang bagian luar, sehingga dapat dikatakan bahwa dinding bata dalam mampu mengambil panas lebih banyak dibandingkan dengan bata dinding luar, hal ini sesuai dengan harga koefisien konduksi bata dalam hasil perhitungan $1,239 \mathrm{~J} / \mathrm{s}{ }^{\circ} \mathrm{C}$ dan bata luarnya $1,567 \mathrm{~J} / \mathrm{s}^{\circ} \mathrm{C}(15)$. 


\section{KESIMPULAN}

Proses perpindahan panas yang terjadi di dalam ruang bakar incinerator adalah perpindahan panas konduksi dan konveksi. Hasil simulasi pemodelan menggunakan perangkat lunak computational fluid dynamics ini diperoleh hasil keluaran berupa data-data distribusi temperatur dan gambar kontur temperatur. Pada tempat di mana proses pembakaran berlangsung diperoleh harga temperatur optimum sekitar $500{ }^{\circ} \mathrm{C}$ sampai $600^{\circ} \mathrm{C}$. Perhitungan karakteristik termofluida yang meliputi panas yang mengalir $(Q)$ dan koefisien perpindahan panas $(\mathrm{h})$ pada tiga (3) titik pengukuran arah aksial diperoleh hasil koefisien perpindahan panas konveksi di ruang bagian dalam lebih besar 10 kali dari koefisien perpindahan panas konveksi di ruang bagian luar antara bata dalam dan bata luar.

\section{DAFTAR PUSTAKA}

1. Ibnu Umar. Pengolahan sampah secara terpadu di wilayah perkotaan. J Lingkungan Hidup. 2009 April 5:5-7.

2. Michael Hutagalung. Teknologi pengolahan sampah. Majari Magazine for Chemical Engneering Students. 2007 Desember 30:1-3

3. Arie Ikhwan Saputra. Manfaat dan dampak penggunaan incinerator terhadap lingkungan. J Teknis. 2013 October 06: 1-3.

4. Andiramuhammad. Teknik pembakaran. 2013 Maret 4. Available from: URL:http//www/blogspot.com/teknik pembakaran/ html.

5. Indriati Sri Wardhani V dan Henky Poedjo Rahardjo. Analisis distribusi temperatur pembakar limbah radioaktif tipe HK-2010 . Prosiding Seminar Nasional Sains dan Teknologi Nuklir. Bandung 2011 Juni 22:78-83.

6. Jotho J. Uji eksperimental pengaruh perubahan temperatur lorong udara terhadap koefisien perpindahan panas konveksi pelat datar. J Teknik Mesin -Fakultas Teknik Universitas Pandanaran. 2010;8;16: 52-55.

7. Anonymous, Fluent/UNS \& Rampant.4.2, user's guide vol.2., Lebanon, June 1997, 8-3 - 8-5.

8. Anonymous, Fluent/UNS \& Rampant.4.2, Fluent Incorporated user's guide vol.3., Lebanon, 1997 chapters 14-16, 14-2 14-7.

9. David W Hahn, Necati Ozisik M, Heat Conduction, John Willey \& Sons. 2012 August 13 th, 122-129.

10.Donald R. Pitts, Leighton E. Sissom, Heat transfer $2^{\text {nd }}$ ed, Schaum's Outline Series, New York. 2012, 111 - 121.

11.Luqman Buchori. Perpindahan Panas heat Transfer); 2013. Available from : Http://tekim.undip.ac.id/images/download IPERPINDAHAN PANAS.pdf.

12.Jhon Fiter Siregar dan Jorfri B Sinaga. Perancangan alat uji gesekan aliran di dalam saluran. J FEMA. 2013;1;1: 75-76.

13.Basri. Analisis pengaruh laju aliran massa terhadap koefisien perpindahan panas rata-rata pada pipa kapiler di mesin refrigerasi focus 808 . J Mekanikal.2011;2;1:16-22.

14.Indriati Sri Wardhani V, Henky Poedjo Rahardjo, Putranto Ilham Yazid. Unjuk kerja pendinginan teras reaktor nuklir daya $1000 \mathrm{~kW}$ dengan perangkat lunak 
Jurnal Sains dan Teknologi Nuklir Indonesia

Indonesian Journal of Nuclear Science and Technology

Vol. 16, No 1, Februari 2015; 41-50

computational fuid dynamics. Prosiding

Seminar Nasional Thermofluid. Fakultas

Teknik Mesin \& Industri Universitas

Gajah Mada, Yogyakarta, Penerbit UGM, 2010:210-213.

15. Henky Poedjo Rahardjo. Karakteristik

temperatur dan reduksi limbah radioaktif padat ruang bakar prototipe tungku HK-
2010. JSTNI 2013;14(1):46-47.

16. Inawati Tanto, Pengukuran konduktivitas panas bata pembakar sampah radioaktif tipe HK-2010. Laporan Teknis hasil penelitian, 2010. 